\title{
An assessment of changes in the montane forests of Taraba State, Nigeria, over the past 30 years
}

\author{
Hazel M. Chapman, Steven M. Olson and David Trumm
}

\begin{abstract}
During October-December 2002 a team from the University of Canterbury, New Zealand, the Nigerian Conservation Foundation and the Nigerian National Parks visited the montane forests of Taraba State, eastern Nigeria. Their aim was to identify changes in the forests that had occurred since they were last described in detail during the 1970s. Then the forests were rich in Afromontane endemics, were home to at least 24 threatened plant species, and harboured abundant wildlife. In 2002 all but one of the forest fragments visited were intact, although some of the smaller fragments had
\end{abstract}

further reduced in size. The most obvious differences between 2002 and the 1970s were the dramatic reduction in wildlife, and the depletion of montane grassland and associated species. For these forests and their associated fauna to survive, more local, national and global support is urgently required for management to prevent species loss.

Keywords Afromontane endemics, Cameroon Highlands ecoregion, Gashaka Gumti National Park, montane forest, Nigeria.

\section{Introduction}

Nigerian montane forests are important because they contain satellite populations of many Afromontane endemics (Dowsett-Lemaire, 1989), are of a rare dry forest type (Akinsoji, 1994) and harbour many threatened plant (Chapman \& Chapman, 2001) and animal (Dowsett-Lemaire, 1989; Dunn, 1993; Kormos, 2003) species. They fall within the Cameroon Mountains Endemic Bird Area (Stattersfield et al., 1998). The Taraba State mountains are north-east outliers within the Cameroon Highlands ecoregion (Olson et al., 2001) (Fig. 1). Their forests range in altitude from 1,650 to 2,420 m on Gangirwal, Nigeria's highest mountain, and vary in size from small fragments of $<1$ ha and riverine strips to stands of $>46 \mathrm{~km}^{2}$. Most of the forests described here lie within Gashaka Gumti National Park (Fig. 1) and are mostly restricted to stream banks and steep, less accessible areas. Many are within enclaves - areas of the Park set aside for grazing and farming (Dunn, 1999). Ngel Nyaki and Kurmin Danko forests are outside the Park, but are Taraba State Forest Department Reserves.

Hazel Chapman (Corresponding author) School of Biology, University of Canterbury, Private Bag 4800, Christchurch, New Zealand.

E-mail hazel.chapman@canterbury.ac.nz

Steven M. Olson School of Forestry, University of Canterbury, Private Bag 4800, Christchurch, New Zealand.

David Trumm Environmental Scientist, CRL Energy Ltd, Christchurch, New Zealand.

Received 25 March 2003. Revision requested 19 June 2003 Accepted 4 March 2004.
During the 1970s J.D. Chapman carried out a detailed botanical survey of the Taraba State montane forests and noted how vulnerable they were to burning and land clearance for farming (Chapman \& Chapman, 2001). As the area had not then been designated a National Park the only forest with any real protection was Ngel Nyaki Forest Reserve (Fig. 1). Since then the situation has changed. Gashaka Gumti was decreed a National Park in 1991, with the condition that the local Fulani pastoralists could remain in enclaves within the Park, grazing cattle and farming. Three of these enclaves are in montane areas. Also, since the early 1980s, the Nigerian Forest Service has suffered from chronic underfunding.

As only one brief survey of Taraba's montane forests had been made since the 1970s (Dowsett-Lemaire, 1989) it was important to reassess their situation in the light of past identified threats and changes in protection. Findings would contribute towards National Park and Forest Service management decisions, and to an updated plant species checklist (Chapman \& Chapman, 2001). During October-November 2002 the team carried out a survey of the Taraba State montane forests, wherever possible visiting the same locations described in Chapman \& Chapman (2001). Here we outline the current status of these forests, describe how they have changed since the 1970s, and highlight current threats.

\section{Methods}

We visited each of the montane forests surveyed by J.D. Chapman (Fig. 1), spending four days on Chappal Hendu, three in Dutsin Lamba, one in Leinde Fadali, four 


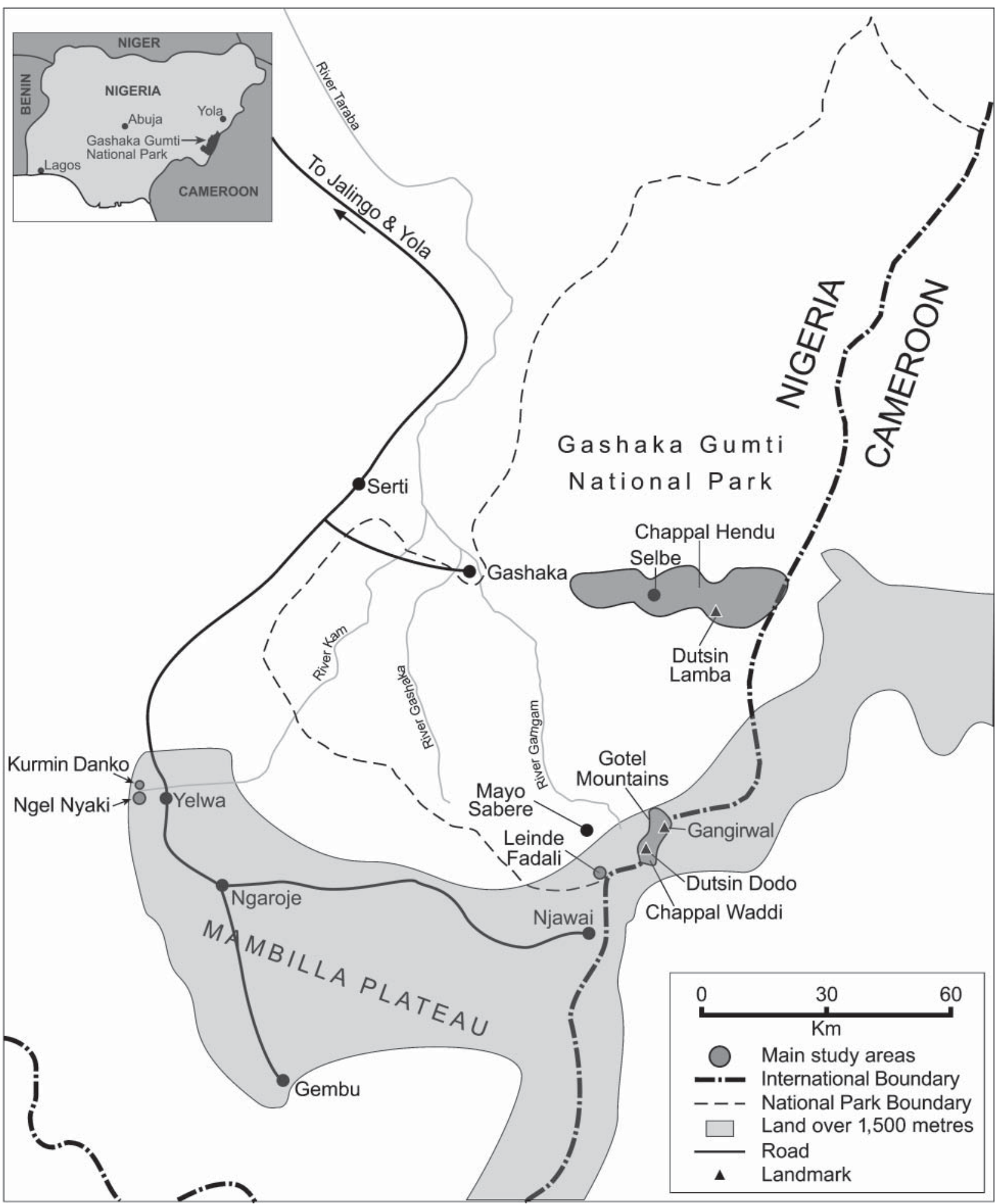

Fig. 1 Gashaka Gumti National Park and the Mambilla Plateau, with the locations of the forests surveyed. The inset shows the position of the main figure within eastern Nigeria.

on Chappal Waddi, three on Gangirwal and four in Ngel Nyaki and Kurmin Danko. With help from the same rangers who had worked with Chapman during the 1970s we were sometimes able to revisit his original enumeration plots. However the time available did not permit a comparable survey; the 1970s work involved 
weeks at each site, collecting profile and enumeration data on every tree within a plot, over 3,000 herbarium specimens, and soil analysis (Chapman \& Chapman, 2001). During the 2002 survey we were only able to describe the dominant plant species in each forest and identify as many others as possible. We made botanical collections for identification purposes and for the herbarium at the National Park Headquarters, Gashaka Village. Our plant nomenclature follows that of Lebrun \& Stork (1991-1997).

The presence of mammals was noted using direct (sightings) and indirect (dung, tracks, marks and calls) observations. These observations were mainly made by Saidu Isa, a Park ranger, and Matt Walters, our photographer, who spent most days at each site specifically looking for mammals. Saidu Isa assisted in assigning species to indirect observations, and as he was originally a very good hunter, his identifications are credible.

\section{Results}

\section{Chappal Hendu and Dutsin Lamba}

Chappal Hendu (Fig. 1) is $28.5 \mathrm{~km}^{2}$ of undulating grassland plateau, c. 1,680 $\mathrm{m}$ in elevation with forest fragments confined to stream sides (Plate 1). The $c .7 .5 \mathrm{~km}^{2}$ of forest known as Dutsin Lamba $(2,100 \mathrm{~m})$ is the highest point on Chappal Hendu; the forest is confined to the steep westfacing slopes. Fulani first grazed their cattle on Chappal Hendu in the 1950s (Morris, 1950). When the plateau became an enclave of the Gashaka Gumti Game Sanctuary in 1972, its human population was several hundred, confined to Selbe village except for transient Fulani camps. Cattle numbers were sufficiently low to pose little threat to the montane grassland. Two types of riparian forest were then common on Chappal Hendu: Syzigium guineense var. guineense - Albizia gummifera, and

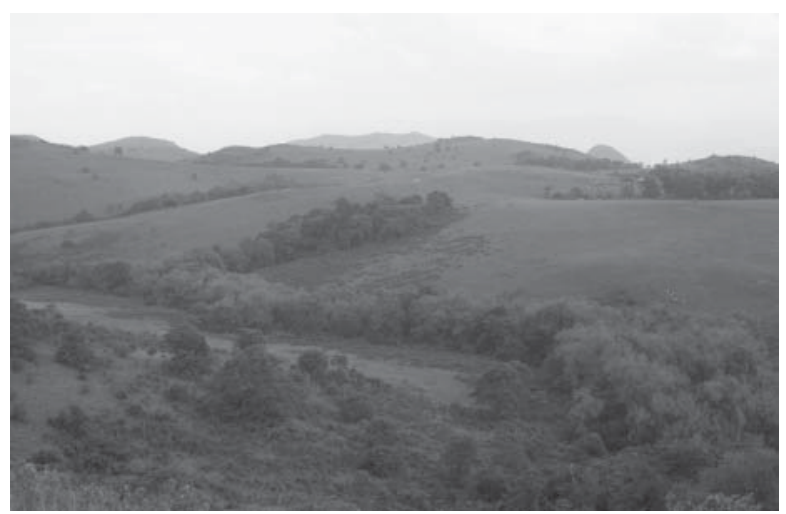

Plate 1 A riverside forest in the enclave Chappal Hendu (see Fig. 1 for location), which has become almost a monoculture of S. guineense var. guineense.
Symphonia globulifera - Garcinia smeathmannii (Chapman \& Chapman, 2001). Both had obviously been cut-over in the past, as species indicative of disturbance such as Croton macrostachyus and Harungana madagascariensis were common. Elyonurus argenteus, a tussock grass intolerant to cattle grazing, extended over several acres of river flat in the central part of the plateau, and the streams were lined with the Near Threatened herb Lobelia columnaris. Common forest edge shrubs were Dissotis elliottii var. elliottii and Hypericum revolutum subsp. revolutum, with fire-resistant Agarista salicifolia often present.

In Dutsin Lamba forest, which is just outside the enclave, several more threatened tree species were present in the 1970s (Table 1), and its surrounding grassland was rich in wildlife (Table 2). It was common to see 40 bushbuck a day, groups of $c .15$ buffalo, and numerous warthog (Barnwell, 1993; J.D. Chapman, pers. comm.). Cattle were rare because of the potential occurrence of tsetse.

By the late 1990s 850 Fulani were resident on Chappal Hendu (Dunn et al., 1998), and in January 2002 there was an influx of more Fulani and their cattle following land rights disputes between the Fulani and Mambilla people living on Mambilla Plateau. This increase in population has accelerated the pressure on the environment (A. Nicholas, pers. comm.). Forest fragments are now restricted to stream banks, where their survival is precarious because of wood extraction and cattle trampling. None of these fragments has the floristic diversity or tall trees of the 1970s. For example, Newtonia buchananii, then common (Chapman \& Chapman, 2001), was not seen in 2002 , and several fragments have been reduced to almost monocultures of S. guineense subsp. guineense. Especially noticeable was the total destruction of a S. globulifera G. smeathmannii forest on the western slopes of Chappal Hendu, which was cleared for farming during the mid 1980s. Although the farmers were moved out in 1993 (R. Barnwell, pers. comm.) cattle still grazed in the area, preventing regeneration. The tussock grass E. argenteus (see above) has mainly disappeared, and L. columnaris is uncommon. Sporobolus grass, tolerant of cattle grazing (Bawden \& Tuley, 1966), has almost totally replaced Hyparrhenia and Loudetia spp. Everywhere on Chappal Hendu suffers from cattle grazing, trampling and a consequent reduction in regeneration. Erosion is especially severe along tracks.

There have been major changes on Dutsin Lamba. Cattle now graze all along the forest edge, entering it and causing damage, especially along streams. There has been an almost total depletion of grassland species sensitive to grazing. For example, in 2002 no Erica mannii or Gladiolus melleri were observed, and Sopubia ramosa was confined to the very top of the highest hill on Dutsin 
Table 1 Plant species identified by J.D. Chapman in the 1970s and now on the 2003 IUCN Red List (IUCN, 2003). A cross (+) indicates a species was found at this location.

\begin{tabular}{|c|c|c|c|c|c|c|}
\hline \multirow[b]{2}{*}{ Species } & \multirow[b]{2}{*}{ Family (lifeform) } & \multirow[b]{2}{*}{ Red List status } & \multicolumn{4}{|l|}{ Area } \\
\hline & & & $\begin{array}{l}\text { Chappal Hendu \& } \\
\text { Dutsin Lamba }\end{array}$ & $\begin{array}{l}\text { Leinde } \\
\text { Fadali }\end{array}$ & $\begin{array}{l}\text { Chappal Waddi } \\
\text { \& Gangirwal }\end{array}$ & $\begin{array}{l}\text { Ngel } \\
\text { Nyaki }\end{array}$ \\
\hline \multicolumn{7}{|l|}{ Dicotyledons } \\
\hline Lobelia columnaris* & Campanulaceae (herb) & $\mathrm{LR} / \mathrm{nt}$ & + & + & + & \\
\hline $\begin{array}{l}\text { Wahlenbergia ramosissima } \\
\text { subsp. ramosissima }\end{array}$ & Campanulaceae (herb) & VU & & & + & \\
\hline Bafutia tenuicaulis & Compositae (herb) & $\mathrm{LR} / \mathrm{nt}$ & & & + & \\
\hline Helichrysum cameroonense* & Compositae (herb) & $\mathrm{LR} / \mathrm{nt}$ & & & + & \\
\hline Vernonia bamendae & Compositae (herb) & VU & & & + & \\
\hline Succisa trichotocephala* & Dipsacaceae (herb) & VU & & & + & \\
\hline $\begin{array}{l}\text { Stachys pseudohumifusa } \\
\text { subsp. saxeri }\end{array}$ & Labiate (herb) & VU & & & & + \\
\hline Entandrophragma angolense* & Meliaceae (tree) & VU & + & + & + & + \\
\hline Khaya grandifoliola* & Meliaceae (tree) & vU & & & & + \\
\hline Lovoa trichilioides* & Meliaceae (tree) & VU & & & & + \\
\hline Eugenia gilgii* & Myrtaceae (tree) & $\mathrm{CR}$ & & & + & \\
\hline Prunus africana* & Rosaceae (tree) & $\mathrm{LR} / \mathrm{nt}$ & + & & + & \\
\hline Pouteria altissima* & Sapotaceae (tree) & $\mathrm{LR} / \mathrm{cd}$ & + & + & + & + \\
\hline Dombeya cf ledermannii ${ }^{*}$ & Sterculiaceae (tree) & CR & + & + & + & + \\
\hline Peucedanum angustisectum & Umbelliferae (herb) & $\mathrm{LR} / \mathrm{nt}$ & & & & + \\
\hline \multicolumn{7}{|l|}{ Monycotyledons } \\
\hline Carex preussii & Cyperaceae & $\mathrm{LR} / \mathrm{nt}$ & & & + & \\
\hline Eriocaulon asteroides & Eriocaulaceae & VU & & & + & \\
\hline
\end{tabular}

* Species identified again in 2002

Lamba. L. columnaris is now rare. There has likewise been a major depletion in wildlife: only five buffalo and two bushbuck were observed during 6 days on Dutsin Lamba in 2002 (Table 2).

\section{The Gotel Mountains (Chappal Waddi and Gangirwal)}

The Gotel Mountains (Fig. 1) are c. $21 \mathrm{~km}^{2}$ of plateau including Chappal Waddi (1,525-1,830 m) and the larger Gangirwal (1,830-2,400 m). The most extensive forests are on the west-facing slopes, where they extend over altitudes of 1,300-1,800 $\mathrm{m}$ and cover an area of $c .46 \mathrm{~km}^{2}$. Forest vegetation persists upwards into the plateau grassland along the banks of streams, and the highest patch is at $2,300 \mathrm{~m}$.

During the 1970s two forest types were identified at 1,830 m: A. gummifera - Nuxia congesta forest and Pouteria altissima dominated forest (Chapman \& Chapman, 2001). In the former the threatened species Entandrophragma angolense, Eugenia gilgii, Millettia conraui and P. altissima were present, and in the latter all of the above plus Dombeya ledermannii (Table 1). The forests above 2,000 m were described as Prunus africana - S. guineense subsp. bamendae - Podocarpus latifolius forest and S. guineense subsp. bamendae stream source forest (Chapman \& Chapman, 2001). They were less diverse than forests at lower altitudes, and the tallest trees reached only $20 \mathrm{~m}$ at 2,000 m elevation, and only $9 \mathrm{~m}$ at 2,300 $\mathrm{m}$.

During the 1970s cattle grazing was confined to the lower slopes of Chappal Waddi (J.D. Chapman, pers. comm.). As a consequence species sensitive to grazing such as Blaeria spicata, S. ramosa, E. mannii and Delphinium dasycaulon were common, as were the threatened herbs Helichrysum cameroonense, scattered amongst the Loudetia simplex tussocks, and Bafutia tenuicaulis around rocky outcrops (Table 1). Few poachers, deterred both by superstition associated with the rock outcrop Dutsin Dodo (Plate 2) and its inaccessibility, explained the abundance of wildlife (R. Barnwell, pers. comm.; J.D. Chapman, pers. comm.) (Table 2).

In 2002 the situation was different, despite Chappal Waddi and Gangirwal being within Gashaka Gumti National Park. Superficially the area appeared similar to the 1970s, with the large tracts of forest below Dutsin Dodo and Gangirwal remaining much the same. However on Chappal Waddi we came across $>20$ poachers, from both Nigeria and Cameroon, with sackfuls of lichen and tubers to be sold for medicinal and culinary uses. The wildlife has been decimated since the 1970s; a wellused hunter's track now runs below Dutsin Dodo along a spur leading down to Mayo Sabere village. During our 10 days on the mountain the only wildlife we saw were 


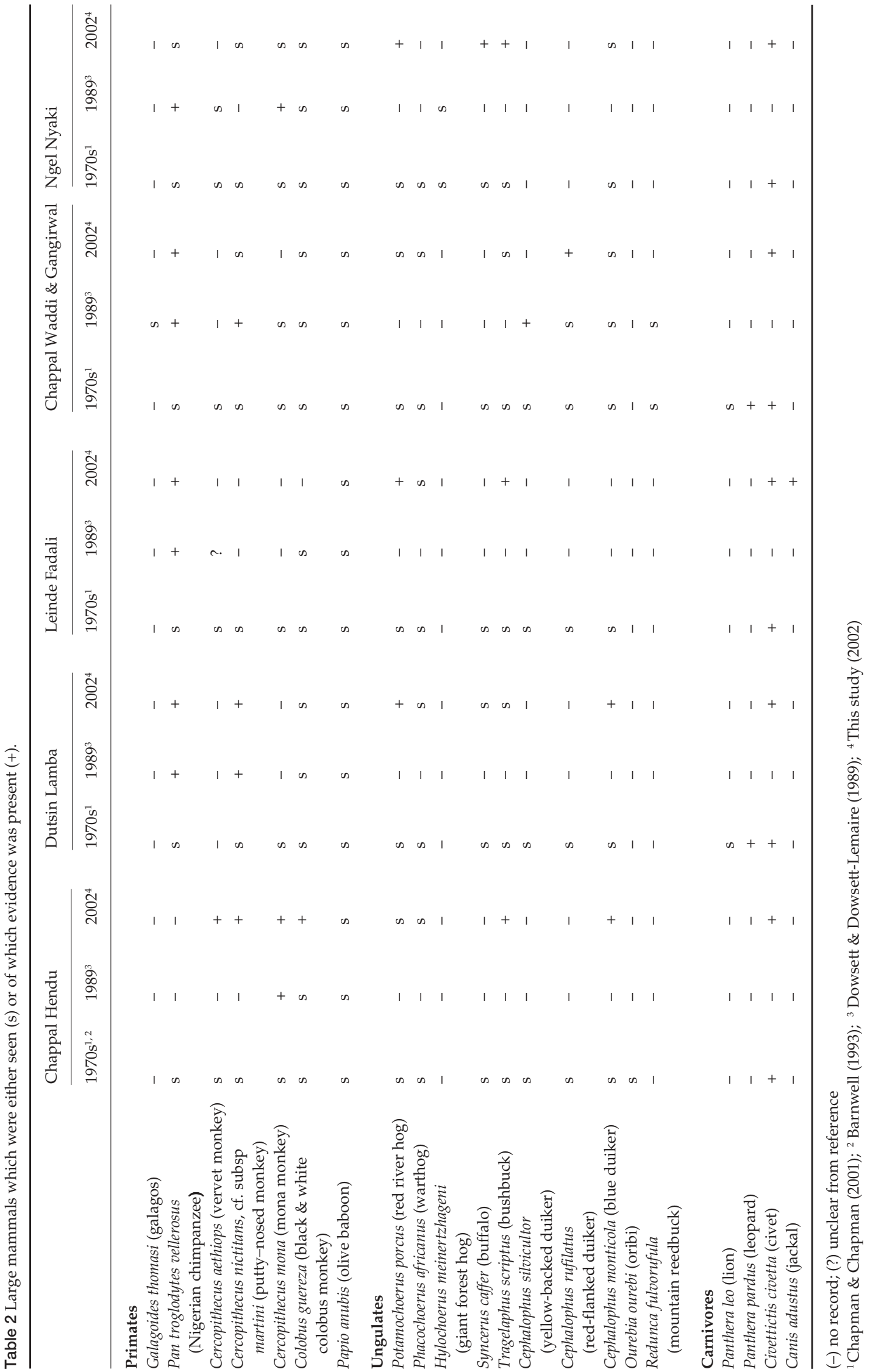




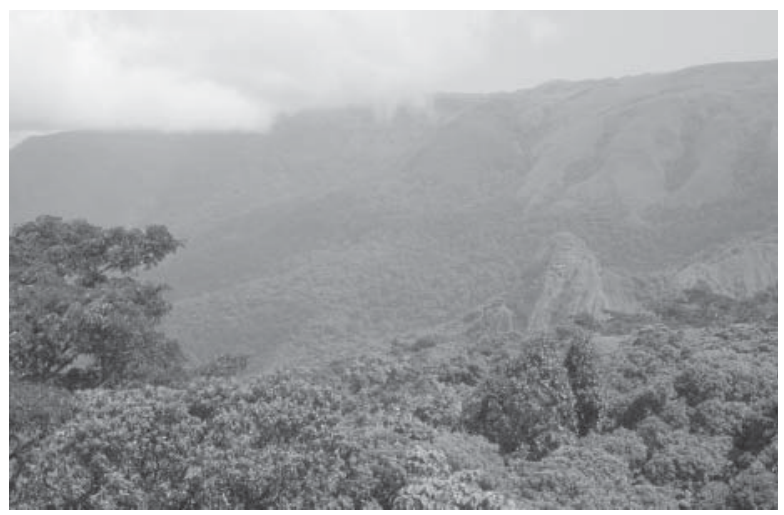

Plate 2 An area of extensive sub-montane and montane forest on Chappal Waddi (see Fig. 1 for location). The rock outcrop Dutsin Dodo is in the foreground.

two jackal Canis adustus, several colobus monkeys Colobus guereza and some baboons Papio anubis (Table 2).

On the upper reaches of Gangirwal Fulani herdsmen and their shelters are tolerated by the Park game guards, and we saw evidence of cattle everywhere on the mountain. Patches of grassland are dominated by kikuyu grass, Pennisetum clandestinum, an introduced species restricted to cattle holding sites. E. mannii and S. ramosa are now restricted to steep cattle-free slopes, and bracken, Pteridium aquilinum, has spread into the grassland. Cattle-induced soil erosion and compaction is especially pronounced in gullies and along tracks. Fires have continued to encroach along the forest edge, and in some places on Chappal Waddi the shrubby ecotone has been destroyed.

\section{Ngel Nyaki and Kurmin Danko}

Located towards the western escarpment of Mambilla plateau, over 1,400-1,600 m (Fig. 1), Ngel Nyaki forest comprises c. $7.2 \mathrm{~km}^{2}$ of sub-montane to mid-altitude forest. The forest is visible from the road, and is just less than an hour's walk from the village of Yelwa (Fig. 1). In the 1970s Ngel Nyaki was patrolled regularly by forest guards, and was also under the unofficial protection of Jauro Patel, the chief of Yelwa. Poaching was rare, and farmers respected the reserve boundary. Ngel Nyaki was the most floristically diverse sub-montane forest in Nigeria. It harboured several threatened species (Table 1) and others unknown at that time elsewhere in West Africa (Anthonotha noldeae, Apodytes dimidiata and Pterygota mildbraedii) and Nigeria (Ficus chlamydocarpa and Isolona cf. deightonii) (Dowsett-Lemaire, 1989). This diverse forest flora was reflected in the high number of primates and other animal species (Table 2), and high bird species diversity (Hall, 1976; Ash et al., 1989).
In 2002 we found physical damage to the forest: slash and burn agriculture was infringing on the lower slopes of the reserve, there were several abandoned farms of c. $1.5 \mathrm{~km}^{2}$ within the reserve boundary, and cattle trampling within the forest and along its edge was causing soil erosion. Hunting pressure was higher than in any of the other forests that we visited and during our 5 days there we found several leg-hold spring traps and snares, some containing duiker. Informants (local people from Yelwa village who sometimes patrol the forest for hunters on a voluntary basis), presented us with a further 22 wire snares that they had collected over the previous few months.

Surprisingly, despite the obvious poaching pressures, mammals and birds were still relatively abundant. Primates were not especially shy; we saw a troop of at least 30 putty-nose monkeys Cercopithecus aethiops and a family of chimpanzees Pan troglodytes vellerosus, as well as several chimpanzee nests. Black and white colobus monkeys, many baboons and c. 10 buffalo Syncerus caffer were also sighted (Table 2). Ngel Nyaki is classified as an Important Bird Area (Fishpool \& Evans, 2001). Neighbouring Kurmin Danko, which was farmed during 1971, and gazetted as a Forest Reserve in 1972, is regenerating well.

\section{Leinde Fadali}

Leinde Fadali (Fig. 1), at 1,300-1,700 m, is a small, isolated forest of $c .4 \mathrm{~km}^{2}$, covering steep ridges and gullies on north-west facing slopes overlooking the village of Mayo Sabere. The forest had no official protection during the 1970s and survived mainly because of its inaccessibility. Floristically Leinde Fadali resembles Ngel Nyaki (Dowsett-Lemaire, 1989; Chapman \& Chapman, 2001).

Despite Leinde Fadali being incorporated into Gashaka Gumti National Park in 1991, the most obvious changes to the forest are associated with increased population pressure. Cattle now graze right up to the forest edge and temporary Fulani shelters are within $100 \mathrm{~m}$ of the reserve boundaries. Cattle enter the forest, and their trampling has led to soil compaction and erosion, especially along stream banks. The scarcity of wildlife observed in 2002 compared with Chapman's 1970s sightings (Table 2) and the obvious timidity of those seen (only a few warthog Phacochoerus africanus and a bushbuck Tragelaphus scriptus) are evidence of intense hunting pressure. However in 2002 chimpanzees were heard and several recently used chimpanzee nests were found. The forest flora is still intact, and we collected a previously unknown Acanthaceae from the genus Metarungia (K. Vollesen, pers. comm.). Its closest relatives are in East Africa. 


\section{Discussion}

\section{Importance of the forests}

African montane forests are of high conservation priority because of their complex origin and evolutionary history (White, 1981, 1983). Approximately 50\% of the tree species described here are Afromontane endemics or near endemics (Dowsett-Lemaire, 1989), and others are mainly confined to the Nigerian/Cameroonian highlands (Hall, 1988). The forests are globally important for their bird fauna (Stattersfield et al., 1998), are rich in larger mammalian species (Table 2), and have a high diversity of smaller mammals, reptiles and amphibians (Dowsett-Lemaire, 1989; Dunn, 1999).

Caps of montane forest in this region are important for watershed conservation. Without this protection little or no water is available in the dry season in many places (Bawden \& Tuley, 1966). Several forest plants are currently used by the local people for food and medicine (Low, 1996), and the forests have potential for ecotourism and outdoor recreation, as on the Obudu Plateau (Oates, 1999). Gashaka Gumti National Park is a potential extension to a wildlife corridor system that stretches in a north-easterly direction from the Park to the Faro, Bénoué and Boubandjida National Parks of Cameroon, all of which harbour many of the larger mammal species formerly found throughout this region of West Africa (Happold, 1973). To this end negotiations between the respective Park Boards are under way (A. Nicholas, pers. comm.).

\section{Changes to the forests}

Overall forest area has not changed greatly since the 1970s, and we found no evidence to suggest that any tree species has become extinct (Table 1). Only one forest on Chappal Hendu has been cleared. However, riverine fragments within the National Park enclaves are becoming smaller, and are less species diverse than formerly. Forest Reserves are under greater threat than in the 1970s; slash and burn agriculture is encroaching on Ngel Nyaki, although Kurmin Danko is regenerating well after its decimation during the early 1970s.

The most obvious changes to the montane environment are the decline in large mammal numbers (Table 2), soil erosion (especially in the grasslands), and change in grassland floristic composition. While it is unlikely that any forest mammal has become extinct (DowsettLemaire, 1989), some species are becoming rare. For example the giant forest hog Hylochoerus meinertzhageni, considered 'probably common' in the Gotel Mountains during the 1980s (Dowsett \& Dowsett-Lemaire, 1989), is not so today. The grassland mountain reedbuck Redunca fulvorufula, common in the 1970s (J.D. Chapman, pers. comm.), was rare in 1989 (Dowsett \& Dowsett-Lemaire, 1989), and we found no evidence of them in 2002 (Table 2).

This dramatic decline in mammal numbers may be very recent on Gangirwal; Saidu Isa reported dramatic declines since his previous visit in 2000. The forests are still rich in bird species (Dunn, 1999; Fishpool \& Evans, 2001) including the great blue tauraco Corythaeola cristata and the bar-tailed trogon Apaloderma vittatum, in contrast to the Kilum-Ijim forest in Cameroon, where most of the larger mammals and the great blue tauraco are now extinct (Maisels et al., 2001). However, the ecology of the smaller fragments and grassland has changed dramatically in response to increased cattle grazing and burning.

\section{Threats to the forests}

The most obvious physical threats facing the forests within Gashaka Gumti National Park, both inside and outside the enclaves, are cattle grazing and fire damage, as on Mt Oku in Cameroon (Cheek et al., 2000). A more subtle threat to forest ecology may be reduced recruitment because of declining frugivore numbers (Cordeiro \& Howe, 2001). Eighty per cent of montane forest trees are animal-dispersed in Malawi (Dowsett-Lemaire, 1988) and Cameroon (Maisels et al., 2001). Chimpanzees are likely to be important seed dispersers of larger seed, especially as other common monkeys are seed-spitting cercopithecines (Chapman, 1995), and because birds with gapes wide enough to ingest large seeds, such as tauracos (T. persa, T. leucolophus and Musophaga violacea) and pigeons (Columba sjostedti) (Dunn, 1999), are now less common (J.D. Chapman, pers. comm.). Trees with large fruits dispersed by animals, which may be especially vulnerable to frugivore decline, include the common S. guineense subsp. guineense and S. guineense subsp. bamendae, Carapa grandiflora and Mystroxylum aethiopica.

In the long- or medium-term the forests described here are in jeopardy of becoming 'empty forests', as have the forests of Ghana's Nini-Suhien National Park (Oates, 1999) and, potentially, the Kilum-Ijim forest of Cameroon (Maisels et al., 2001). Forest Reserves, which receive less protection than forests within the Park, are even more vulnerable to slash and burn agriculture, poaching, grazing and fire.

\section{Recommendations}

The most important recommendation that we can make for Gashaka Gumti National Park is stricter enforcement of existing laws and more effective patrolling by game guards. The 60 game guards currently assigned to montane areas in the Park are insufficient in number (Dunn, 1998), but they would be more effectual if given better incentives to patrol away from their stations. 
A major challenge facing the Park are the enclaves, within which almost half the cattle are owned by Fulani from outside the enclaves (Dunn, 1993). Theoretically Park guards work within the enclave to encourage communities to monitor their areas and report any illegal activities (Dunn, 1998). This is not working, and tensions between them are palpable. Brechin et al. (2002) suggested that long-term solutions to such problems can only come from dialogue among all stakeholders. They stress the need for responsibility and accountability at all levels, and for constant evaluation and assessment. In a similar situation Weladji \& Tchamba (2003) described their success in the Bénoué Wildlife Conservation Area in Cameroon through identifying conflicts on a caseby-case basis, developing tangible benefits to the local people, and including them in management.

Although arguments for incentive-driven conservation are compelling and intuitive, equally so are the arguments by proponents of stricter enforcement, such as Oates $(1995,1999)$ and Terborgh (1999), who have argued that the community-based conservation approach has failed. Under this paradigm one would argue for resettling the local people and cattle outside the Park.

Ngel Nyaki and Kurmin Danko Forest Reserves are in more urgent need of protection than any of the forests within the Park. They should either be incorporated within the Park (R. Barnwell, pers. comm.; A.P. Leventis, pers. comm.) or become the focus of a long-term research project administered through local, national and international bodies (J. Oates, pers. comm.). Either scenario would provide a higher level of protection than now.

The montane forests of Gashaka Gumti National Park and Ngel Nyaki forest cannot be allowed to continue deteriorating due to insufficient patrolling, low levels of support and funding, and poor infrastructure. Much more national and global support is urgently required to combine sustainable, renewable resource management with management that prevents species loss.

\section{Acknowledgements}

Our 2002 forest survey was sponsored by Fauna \& Flora International's 100\% Fund, a Rufford Small Grant, and the Percy Sladen Trust. The Nigerian National Parks, The Nigerian Conservation Foundation and WWF (UK), especially Aaron Nicholas, all provided valuable logistical support. WWF (UK) and BirdLife International supplied reports. For help in the field we thank Saidu Isa, Francis Kamjoh, Marcson Marcus, Laura Sessions and Matthew Walters. Jim Chapman, David Norton and two anonymous reviewers made valuable comments on the manuscript.

\section{References}

Akinsoji, A. (1994) The Vegetation of Gashaka Gumti National Park: A Preliminary Survey. Unpublished Report. Nigerian Conservation Foundation, Nigeria \& WWF UK.

Ash, J.S., Dowsett, R.J. \& Dowsett-Lemaire, F. (1989) New ornithological distribution records from eastern Nigeria. In Tauraco Research Report 1 (ed. R.J. Dowsett), pp. 13-27. Tauraco Press, Ely, UK.

Barnwell, R. (1993) WWF/NCF wildlife conservation initiatives in Nigeria. In Wildlife Conservation in West Africa. Proceedings of the biennial symposium of the Nigerian Field Society (UK Branch) in association with WWF UK. Royal Botanic Gardens, Kew, UK.

Bawden, M. \& Tuley P. (1966). The land resources of southern Sardauna and southern Adamawa provinces, Northern Nigeria. In Land Resource Study, No. 2. Land Resource Division, Directorate of Overseas Surveys, Tolworth, UK. Brechin, S.P., Wilshusen, P.R., Fortwangler, C.L. \& West, P.C. (2002) Beyond the square wheel: toward a more comprehensive understanding of biodiversity conservation as a social and political process. Society $\mathcal{E}$ Natural Resources, 15, 41-64.

Chapman, C. (1995) Primate seed dispersal: coevolution and conservation implications. Evolutionary Anthropology, 4, 74-82.

Chapman, J.D., \& Chapman, H.M. (2001) The Forests of Taraba and Adamawa States, Nigeria. An Ecological Account and Plant Species Checklist. University of Canterbury, Christchurch, New Zealand.

Cheek, M., Onana, J., \& Pollard, B. (2000) The Plants of Mount Oku and the Ijim Ridge, Cameroon: A Conservation Checklist. Royal Botanic Gardens, Kew, UK.

Cordeiro, N. \& Howe, H. (2001) Low recruitment of trees dispersed by animals in African forest fragments. Conservation Biology, 15, 1733-1741.

Dowsett, R.J. \& Dowsett-Lemaire, F. (1989) Larger mammals observed in the Gotel Mts and on the Mambilla Plateau, eastern Nigeria. In Tauraco Research Report 1 (ed. R.J. Dowsett), pp. 38-41. Tauraco Press, Ely, UK.

Dowsett-Lemaire, F. (1988) Fruit choice and seed dissemination by birds and mammals in the evergreen forests of upland Malawi. Revue d'Ecologie (Terre et Vie), 43, 251-285.

Dowsett-Lemaire, F. (1989) Physiography and vegetation of the highland forests of eastern Nigeria. Tauraco Research Report, 1, 6-12.

Dunn, A. (1993) A Preliminary Survey of the Forest Animals of Gashaka Gumti National Park, Nigeria. Unpublished Report. WWF UK \& Nigerian Conservation Foundation, Nigeria.

Dunn, A. (1998) Gashaka Gumti National Park: A Management Plan for Developing the Park and its Support Zone. Draft Unpublished Report. Nigerian Conservation Foundation, Nigeria and WWF.

Dunn, A. (1999) Gashaka Gumti National Park - A Guide Book. National Parks Service of Nigeria in collaboration with the Nigerian Conservation Foundation \& WWF, Lagos, Nigeria Fishpool, L.D.C. \& Evans, M.I. (2001) Important Bird Areas in Africa and Associated Islands. Pisces Publications, Newbury, UK

Hall, J.B. (1988) Highlands of Eastern Nigeria: A Re-examination of Conservation Interest. Nigerian Field Society Symposium on the Conservation of Nigerian Ecosystems, Flora and Fauna, held at Corpus Christi College, Cambridge, 8-9 July 1988. 31 pp. typescript (including appended lists). 
Hall, P. (1976) The birds of Mambilla Plateau. Bulletin of the Nigerian Ornithological Society, 12, 67-72.

Happold, D. (1973) Large Mammals of West Africa. Longman, Singapore.

IUCN (2003) 2003 IUCN Red List of Threatened Species. IUCN, Gland, Switzerland [http:/ / www.redlist.org, accessed 13 May 2004].

Kormos, R. (2003) Urgent action needed for West African chimpanzees. Oryx , 37, 16-17.

Lebrun, J.P. \& Stork, A.L. (1991-1997). Énumération des Plantes à Fleurs D'Afrique Tropicale. Geneva, Ville de Geneve, Switzerland.

Low, L. (1996) Non-timber Forest Products: A Study of Their Use and Value to the People of Gashaka Gumti National Park, Nigeria. MSc thesis, University College London, London, UK.

Maisels, F., Keming, E., Kemei, M. \& Toh, C. (2001) The extirpation of large mammals and implications for montane forest conservation: the case of the Kilum-Ijim Forest, North West Province, Cameroon. Oryx, 35, 322-331.

Morris, L.J. (1950) The Filinga Plateau and Adjoining Areas. Departmental Report. Unpublished Report, Ministry of Animal and Forest Resources, Northern Nigeria.

Oates, J. (1995) The dangers of conservation by rural development - a case study from the forests of Nigeria. Oryx, 29, 115-122.

Oates, J. (1999) Myth and Reality in the Rainforest: How Conservation Strategies are Failing in West Africa. University of California Press, Berkley, USA.

Olson, D.M., Dinerstein, E., Wikramanayake, E.D., Burgess, N.D., Powell, G.V.N., Underwood, E.C., D'Amico, J.A., Itoua, I., Strand, H.E., Morrison, J.C., Loucks, C.J., Allnutt, T.F., Ricketts, T.H., Kura, Y., Lamoreux, J.F., Wettengel,
W.W., Hedao, P. \& Kassem K.R. (2001) Terrestrial ecoregions of the worlds: a new map of life on Earth. Bioscience, 51, 933-938.

Stattersfield, A.J., Crosby, M.J., Long, A.J. \& Wedge, D.C. (1998). Endemic Bird Areas of the World: Priorities for Biodiversity Conservation. BirdLife International, Cambridge, UK.

Terborgh, J. (1999) Requiem for Nature. Island Press, Washington, DC, USA

Weladji, R. \& Tchamba, M. (2003) Conflict between people and protected areas within the Bénoué Wildlife Conservation Area, North Cameroon. Oryx, 37, 72-79.

White, F. (1981) The history of the Afromontane archipelago and the scientific need for its conservation. African Journal of Ecology, 19, 33-54.

White, F. (1983) The Vegetation of Africa. UNESCO, Paris, France.

\section{Biographical sketches}

Hazel Chapman is Director of the Nigerian Montane Forest Project, which aims to combine biological research with conservation for the sustainable management of the forests.

Steven Olson's research interests focus on the interface between social and ecological dimensions of sustainable resource management.

David Trumm is a geologist with research interests in tropical lianes and plant animal interactions. 